[Penultimate draft]

Forthcoming in How to Make-Believe: The Fictional Truths of the Representational Arts, edited by J. Alexander Bareis and Lene Nordrum. Berlin: De Gruyter, 2015.

\author{
Eran Guter and Inbal Guter
}

\title{
Impurely Musical Make-Believe
}

The mode of narration appropriate to absolute music, that is, "pure instrumental music without text, title, programme, dramatic setting, or any other extraordinary music apparatus" (Kivy 2009, 157), has been a matter of controversy in contemporary Anglophone philosophy of music for some three decades. Musicologist Anthony Newcomb put the issue succinctly:

A large component of most music lies in its power [...] to delight with its patterns in sound. (Hanslick likened music to the arabesque and the kaleidoscope.) But in some music these patterns seem to force upon some of us recognition of meaning connected to other aspects of our life - of a representational and expressive power. (Newcomb 1997, 132)

The crux of the problem is the conviction, which germinated in Eduard Hanslick's seminal treatise On the Musically Beautiful (Hanslick 1986 [1885]), that pure instrumental music lacks representational, narrative, semantic, or other extra-musical content, hence whatever meaning such music has consists in what Richard Wollheim $(1987,45)$ called "the much maligned property of the decorative." Yet arguably, such extra-musical content, and accordingly, the power of music to be "about" such content in some sense, seem to play a prominent role in our understanding and appreciation of pure instrumental music and seem vital to the value that it holds for us. Without extra-musical content we are left with pure repetitive form. The problem concerning the mode of narration appropriate to absolute music patently relates to the unique unfolding of such music qua "the fine art of repetition," to use the catchy title of a book by Peter Kivy (1993a). It is not at all clear how we might explain why and how pure repetitive patterns of sound relate to our lives, or whether we can do so at all.

In this paper we probe this problem in the somewhat unexpected context of Kendall Walton's theory of ornamentality. In his seminal book, Mimesis as Make-Believe (1990), and in a number of other papers $(1986 ; 1988 ; 1994 ; 1999 ; 2011 ; 2012)$, Walton carefully integrated the art of music into his theory of the representational arts, arguing that not only bona fide instances of programme music, but also works of so-called absolute music are thoroughly capable of generating fictional truths by engaging the listeners with props in introspectively imaginative games of make-believe. Hence our discussion in this paper is bound to read Walton against the grain. Yet one of the philosophically attractive features of Walton's theory of make-believe is the way that it is couched in terms of imaginative transactions with artifacts, placing homo ludens in the limelight. Walton gives unusual precedence to the experiencing subject - what would she identify as props, and how would she use them in appropriate games of makebelieve? In our discussion we will tap into this essentially Waltonian intuition in order to show that a possible remedy for the problem concerning the mode of narration appropriate to absolute music can actually be found in his fruitful ideas on ornamentality. 
For an elegant initial setup for our discussion we turn to a famous passage from E. M. Forster's novel Howards End, which Peter Kivy wittily invoked in his book Music Alone (Kivy 1990). In this passage, four characters are listening to Beethoven's fifth symphony, "the most sublime noise that has ever penetrated into the ear of man" (Forster 1963 [1910], 31). Two of the listeners in that scene - Helen Schlegel and her younger brother Tibby - are of particular importance for Kivy as well as for our present concerns, since they exemplify seemingly incompatible types or modes of listening to music. Helen - "who can see heroes and shipwrecks in the music's flood" (31) - dwells on imaginative introspection; Tibby - "who is profoundly versed in counterpoint, and holds the full score open on his knee" (31) - savors tönend-bewegte Formen. For Kivy, an eminent advocate of formalism, this sharp contrast between Helen-type listening and Tibby-type listening ultimately means that Helen cannot really be a pure listener "of the work." Rather, Helen-type listening is a case of attending an amalgamation of the music per se with the listener's own imaginative, introspective, often unruly contribution. Since, according to Kivy $(1990,91)$, "our enjoyment of music is of cognitively perceived musical sound," only Tibby-type listening is justifiable as a genuine experience of pure instrumental music.

To be sure, postulating the mutual exclusivity of these two types of listening is unwarranted. Indeed, under the pressure of criticism, Kivy eventually withdrew his original claim concerning the unique authenticity of Tibby-type listening, admitting that neither his metaphysical nor his consequentialist strategies in Music Alone for establishing the claim that "pure" music requires "pure" listening are viable (Kivy 1993b). However, we may still regard the Tibby-Helen distinction as opening up, and charting, a continuous rich spectrum of congruent modes of listening. Thus, our investigation is driven by the following initial questions: (1) Can Walton's theory of make-believe accommodate such a continuum? (2) How may such accommodation intervene in the current philosophical debate concerning the problem of absolute music?

\section{Formalism and narrativism}

Let us begin by situating our discussion vis-à-vis the current debate on the subject. In Antithetical Arts: On the Ancient Quarrel between Literature and Music (2009), Peter Kivy portrayed the current philosophical divide concerning the problem of absolute music as a watershed in aesthetic thought between two opposing traditions about how to understand music: formalism and narrativism. According to Kivy, whereas formalists insist that musical meaning inheres solely in the formal features of "music alone," narrativists are actually literary interpreters of absolute music. They employ a literary analogy in order to attribute meaning to pure instrumental music, perhaps even to render absolute music as akin to literary art. Like Helen, they see heroes and shipwrecks in the music's flood: disembodied actions of indeterminate agents. And Forster's original choice of words, employing the verb to see rather than to hear, is actually philosophically important here, because (Kivy argues) this is precisely the problem: We don't really hear heroes and shipwrecks in the music's flood, but rather, quite figuratively, we behold such things in imagination or perceive them mentally, against the music's flood.

The most popular form of present-day narrativism is the "persona theory." The main idea of this theory was first voiced by the musicologist Edward T. Cone $(1974,94)$, who claimed that "any instrumental composition, like the instrumental component of a song, can be interpreted as the symbolic utterance of a virtual persona." Variants of the persona theory were subsequently developed and defended independently by Jerrold Levinson (1990, 306-335) and by Jenefer 
Robinson (2005). Such theories commonly postulate some sort of indefinite persona in the music, which is supposed to serve as a hinge for our deeply felt interest in pure instrumental music. The idea is that just as narrators in literary works express beliefs, attitudes, intentions, and emotions by means of the words of the text, musical personae express emotions (feelings, attitudes) by means of the sounds (or "gestures") of the music. So listeners' experiences, like those of readers, involve something like recognizing and responding to another person, one who experiences and expresses the emotion in question. As Kivy pointed out, the musical persona performs two functions for the narrativist:

[T]o give absolute music a fictional content that is supposed to account for its artistic substance and interest, at least in part; and to explain how absolute music is capable [...] of arousing what I have been calling the "garden-variety" emotions [...] (Kivy 2009, 101)

From the formalist's point of view, the persona theorist wishes to take an easy way out of the problem concerning pure instrumental music (Kivy 2002, 113-119; 2009, 101-117). Persona theory may seem to fare better in explaining why we consider pure instrumental music valuable, or at least it seems to be able to do so more naturally, but only on pain of allowing the uncontrollable overpopulation of the canon of pure instrumental music with shadowy musical personae. The problem is that we cannot individuate such musical personae from one another or re-identify any of them over time in any clear sense. The analogy with the literary model runs out of steam when we come to realize that characters in literary fiction are interesting because they are concrete individuals with relatively rich personal histories who are situated in relatively detailed circumstances; they are not abstract entities, or "empty suits," as Kivy (2002) calls them. In the last analysis, musical personae may possess very few fictional resources to hold our interest or to move us emotionally.

Moreover, construing musical personae as hinges for our emotional involvement with pure instrumental music may involve a number of misconceptions and ambiguities. For instance, Walton $(2011,459)$ made the general point that "on the persona hypothesis, expression turns out to be a species of representation: Music represents itself as someone's expression of feelings, as a story represents itself as someone's reports of a series of events." This eventually muddies some important distinctions between stories and pure instrumental music. But even on their own terms, persona theories seem to falter. Kivy (2009, 107-108) pointed out that in Levinson's account we always feel the same emotion that the musical persona is supposed to be expressing. Characters in literary fiction do not restrict our responses in this way. This might be a result of misconstruing the concept of empathy as mirroring in the sense of taking on the emotion of the persona, ${ }^{1}$ rather than in the sense of reacting to his or her emotion with a different emotion. Robinson's (2005) "new Romantic theory of expression in the arts" follows in the footsteps of Robin George Collingwood (1964 [1938]) by maintaining that readers and listeners take on, experience for themselves, or "recreate in imagination" the emotion they observe in the narrator or persona of an expressive work. However, such a conception might be open mutatis mutandis to the charge, which has already been effectively leveled against Collingwood's original theory, that a work of art can have expressive qualities without there necessarily being a prior act of expression by an (implied) artist. ${ }^{2}$ Stephen Davies (2003) made the important point that the listener projects the purported persona onto the work after the emotive content has already been recognized; hence the musical persona is hardly an essential precondition of expressive hearing.

\footnotetext{
${ }^{1}$ See Levinson 1990, 320-321.

${ }^{2}$ See Tormey 1971.
} 
The arguable demise of the persona theory notwithstanding, Kivy's own enhanced formalism seems to fare no better in explaining why, and how, the empty pleasure of pure instrumental music could be valuable in itself. While the persona theorist may have taken an easy way out, the formalist seems adamant to push things to a state of gridlock. Kivy invariably insists that we cannot explain the appeal of absolute music by appealing to its narrative content, because if it has narrative content then it isn't absolute music qua an art of purely abstract but perhaps expressive sound. ${ }^{3}$ In Antithetical Arts Kivy attempted to account for the value that pure instrumental music holds for us by observing a kinship between the kind of "morally uplifting experience" which such music affords, and the inexplicable notion of mystical experience pertaining to aesthetic emotion which Clive Bell (1958 [1914]) promulgated a century ago: "[W]hat strikes me about Bell's descriptions of his 'aesthetic emotion' are how closely they resemble the kind of ecstatic experience of absolute music I have been trying to describe [...]" (Kivy 2009, 249). In fact, Kivy seems to have aligned himself even more closely with another Bloomsbury aesthetician, Roger Fry $(1920,199)$, who maintained that "those who experience [aesthetic emotion] feel it to have a peculiar quality of 'reality' which makes it a matter of infinite importance in their lives." Fry did not shy from the ultimate conclusion: "Any attempt I might make to explain this would probably land me in the depths of mysticism."

Following a certain reading of Bell by Nicholas Wolterstorff, Kivy appeals to the religious overtones and allusions in Bell's language in order to bathe the empty pleasure of pure instrumental music in profundity. There is no doubt that the members of the Bloomsbury group saw a very close and deep connection between ethics and aesthetics. Yet this connection derives primarily from the conceptual construal of the idea of significant form. Jaakko Hintikka (1995) pointed out that the aesthetics of Bell and Fry was suffused in the epistemology of George Edward Moore, which was predominant in Bloomsbury. The idea that significant forms are the basic objects of aesthetic experience was invariably connected with the idea that objects of acquaintance are the basic data of epistemological experience. Hintikka's point is that significant form is actually analogous to a sense-datum as an object of immediate experience. It is an objective entity; it is not an object (form) that merely appears beautiful, but is rather what we experience as beautiful. However, such aesthetic objects cannot be identified with perceptual objects (patterns of color on canvas) or with the perceptual sense-data whose being consists in exhibiting those patterns. To do so would be to commit the naturalistic fallacy. "Hence," Hintikka $(1995,23)$ concludes, "an object of an aesthetic experience must according to Fry or Bell have intrinsic properties other than perceptual or geometrical ones. It must intrinsically be a bearer of certain values. This is what the Bloomsbury critics express by saying that a significant form must have moral and spiritual values."

Thus, there was nothing religiously mystical about the kind of object to which the Bloomsbury aestheticians attributed the aesthetic emotion. The moral and spiritual values possessed by a significant form are intrinsic properties of what is seen or otherwise perceived in a work of art. The lesson to be learned from this brief historical excursion is that Kivy cannot seriously take recourse to the religious or otherwise mystical overtones of Bell's (or Fry's) idea of the aesthetic emotion without also admitting the much contested conceptual presuppositions of earlytwentieth-century British realism, which served as the ultimate philosophical justification for splicing aesthetics and ethics in Bloomsbury. We remain skeptical whether Kivy would be willing to mount a defense of Moore's epistemology for this particular purpose.

Our survey of the current debate remains incomplete, but it is now full enough to observe the

\footnotetext{
${ }^{3}$ See Kivy 2009, 119-120.
} 
contours of the debate. As things stand, the debate on both sides of the fence seems to have backtracked unwittingly into problematic philosophical presuppositions of yore, at least in the cases of Robinson and Kivy. Nonetheless, each side seems to capture something important about our experience of pure instrumental music. Champions of Helen-type listening are keen to retain the insight so beautifully expressed by Ludwig Wittgenstein (1980, 73): "For me this musical phrase is gesture. It insinuates itself into my life. I adopt it as my own." But, as Stephen Davies $(2003,168)$ observed, while the imaginary narrative of the progress of the musical persona is indeed possible, it follows, and only contingently, the grasping of the music's nature, the recognition of its unity, integrity, symmetry, and so forth, upon which the narrative projection is cast. So Helen cannot do without Tibby. Champions of Tibby-type listening are keen to retain the equally important insight that music actually delights us with its patterns in sound. Yet Tibby might not attain profundity without Helen. To quote again from Wittgenstein $(1980,70)$ : "Understanding music is a manifestation of the life of humankind."

\section{The Tibby-Helen continuum}

We shall now proceed in a direction which might appear counterproductive at first, especially against the backdrop of our discussion in the previous section. We shall focus on understanding pure instrumental music in terms of musical ornamentality.

As noted before, such an understanding of pure instrumental music has been a hallmark of formalism at least since Hanslick, and presumably even as early as Kant (1952 [1790], 72), who suggested ranking "fantasias (without a theme), and indeed, all music that is not set to words" in the same class with "designs à la grecque, foliage for framework or on wallpapers." Hanslick famously argued in On the Musically Beautiful that a certain kind of ornamentation in the visual arts may afford a serviceable image of how music is able to produce beautiful forms without specific feelings as its content. "[L]et us think," he wrote (Hanslick 1986 [1885], 29), "of an arabesque not dead and static, but coming into being in continuous self-formation before our eyes." Also: "Music is a kind of kaleidoscope [...] Music produces beautiful forms and colours in ever more elaborate diversity, gently overflowing, sharply contrasted, always coherent and yet always new, self-contained and self-fulfilled" (29). He qualified this analogy (inconsistently) by admitting that "by contrast with arabesque, music is actually a picture, but one whose subject we cannot grasp in words and subsume under concepts" (30). Still, he seriously begged the question by rendering the distinction between visual ornamentality, which is "no more than a mechanically ingenious plaything," and musical ornamentality, which is an exalted human achievement, in terms of the latter's being a "direct emanation of an artistic spirit" (29).

Kivy (1993a, 348) seized upon this conception, dubbing it "the wallpaper model," and boldly suggested that we bite the bullet: we should retain the consistency of Kant's original insight, which the comparison with wallpaper means to uncompromisingly make plain, that "music, indeed, possesses no content. It is pure, empty decoration: arabesque." Elsewhere (1993a, 360373) he went even further by arguing that pure instrumental music is not an art in the sense of that term most likely to be applied to it in the present day, that is, as a fine art.

However, by focusing here on understanding pure instrumental music in terms of musical ornamentality, we do not wish to endorse or pursue the formalist agenda. To anticipate, Walton's theory affords a much richer conceptual framework for the discussion of musical ornamentality. At this point, we would like to argue that the idea of musical ornamentality 
enables the opening up of a continuous rich spectrum between what we earlier dubbed Tibbytype listening, that is, the kind of musical understanding which typifies the formalist, and Helen-type listening, that is, the kind of musical understanding which typifies the narrativist. In order to do this, we first need to bracket the historical issue concerning the status of music as a fine art, and to dissociate the discussion of musical ornamentality from the formalist agenda.

Kivy's historical line of argument ${ }^{4}$ is that the notion of a fine art was secured in the eighteenth century upon the formation of the modern system of fine arts, ${ }^{5}$ and that its application to music rested on the idea of an essentially representational practice. Subsequent philosophy of art was bound to struggle with the implications of this theory-laden inclusion of pure instrumental music in the modern system of the arts. In reading history in this way, Kivy's strategy is clear: To prompt a re-evaluation of prevailing narrativist proclivities in contemporary Anglophone philosophy of music.

There are two good reasons for bracketing (for the purpose of our present discussion) the historical issue concerning the establishment of music's status as fine art and its ensuing prestige. The first reason is that these are matters on which the account of musical ornamentality per se can remain agnostic. The second reason is that the problem, raised by Kivy may be quite overstated, as Philip Alperson suggested, if there is another way of understanding the notion of the fine arts (as arts of beauty rather than arts of imitative play), which could accommodate musical ornamentality or even both musical representation and musical ornamentality at the same time.

There is yet another reason for dissociating the discussion of musical ornamentality from the formalist agenda: the splicing of these two distinct philosophical strata in the first place was the result of an unnecessary fixation on the visual analogue of the arabesque, a too-literal application of Kant's rather pedestrian example. Kivy's own meditation on a Persian carpet is quite telling in this regard. ${ }^{6}$ The example is cleverly calculated to show precisely what the enhanced formalist needs to say: That music is a multidimensional (i.e., polyphonic), quasisyntactic, and ultimately deeply expressive and deeply moving pattern. Still the arabesque model is neither the only nor even the primary non-musical analogue for musical ornamentality; and more importantly, in some instances of musical ornamentality this model is plainly not the right kind.

According to Alperson $(1992,220)$, "we can find decorative elements within each of the major musical categories of Western instrumental music of melody, harmony and rhythm." Such instances of musical ornamentality run the gamut from local devices such as trills, turns, grace notes, tremolos, and flourishes, through various means of embellishment of melodic passages and of rhythm, to phrasing accents and timbral manipulations, and ultimately to larger compositional practices. "In fact," Alperson $(1992,220)$ submits, "whole musical styles - and thus the history of musical taste and appreciation - may be understood, if not identified, in large part by reference to decorative practice."

It is important to observe that most of the examples in this vast array of musical phenomena actually fall outside of the arabesque model. The gist of the arabesque model is the idea of sequentiality, as shown in Kivy's use of the Persian carpet example to flesh out his account of

\footnotetext{
${ }^{4}$ See Kivy 1993a, 360-373.

${ }^{5}$ See Kristeller 1990.

6 See Kivy 1993a, 349-358.
} 
repetition in classical form. However, not all instances of musical ornamentality are explicable, neatly or even at all, in terms of sequentiality. For example, short trills, turns, grace notes and their ilk are all local phenomena which have no bearing on musical structure. They decorate in the most straightforward sense, and more often than not they can be removed in performance without significant musical loss. The cadenza, which is ornamental with respect to the work as a whole, is patently external to the formal plan of the piece. This is most clear where the cadenza has been composed by someone other than the original composer of the concerto, or is improvised by the performer.

More complex counterexamples can be found in certain calculated uses of such ornamental devices as accelerando and ritardando to undermine sequentiality by way of surprise. For example, in the second movement of Beethoven's Piano Sonata No. 31 in A-flat major, op. 110, the restatement of the opening theme in measures 96-111 is varied with ritard and a tempo markings in its second appearance. One cannot predict this change in tempo since both the antecedent and the consequent phrases return completely and identically, hence they are readily referred to the original statement of the material. Thus, the embellishment of the tempo in the second repetition turns out to be an unexpected interruption, which in effect weakens the sense of sequentiality altogether.

Other instances of musical ornamentality are profoundly a matter of musical practice, products of cultural and social conditions. Consider, for example, the basso continuo in the musical practice of the seventeenth and eighteenth centuries. This is a bass line with appended accidentals and numbers ("figures") that provides the harmonic outline in many of the musical compositions of the Baroque era. Execution of this characteristic notation assumes the proficiency of the player in conveying the "coded information" by realization of the symbols. However, although the symbols may designate particular forms of harmony, they do not prescribe a fixed distribution of the voices. The role of the accompanist is to "fit to each piece a correct performance of its harmony in the proper volume and with a suitable distribution of tones" (Bach [1753/1787] 1949, 174). The practice of basso continuo also encourages the performer to reach beyond the score in the sense of refining the accompaniment with embellishments and varied imitations which are based on the motivic material.

The accompanist needs to practice discretion in striking a good measure of variability against the principal part while avoiding tedious repetition. Even more importantly, he needs to practice discretion in identifying the uniqueness of a certain piece and designing its appropriate accompaniment for the particular occasion of its performance. For instance, he needs to take into consideration the circumstances of the performance, its location and audience, and the size of the ensemble. Consequently, the execution of basso continuo may vary in each performance; it is dependent on the judgment and skill of the accompanist. In sum, to account for the ornamental practice of the basso continuo, we must acknowledge the crucial role played by the accompanist in the compositional process, finalizing and determining a musical composition in accord with its contemporary performance practice. In this case, compositional decisions taken by the performer need not follow a pure compositional method, but rather bring together practice and method. The arabesque model of musical ornamentality falls short of explaining such quintessential cases of musical ornamentality.

The rich variety of musical ornamentality is hardly surprising considering the enormous scope of non-musical ornamentality, which encompasses all kinds of objects and practices, from tapestries to the sleek contours of race cars, from glass-blowing to bodily modification, from interior decoration to social decorum. It is important to observe that in many such cases, the 
ornamental aspect of such objects or practices is perfectly compatible with full-fledged mimesis. If we consider such objects and practices as ornamental, it is not because they each have a certain form, but because they impinge on our way of living in a certain form. So to look for the point of such ornamental objects and practices is to ask how they mesh with our life. One is not likely to take this to be the point of musical ornamentality if one takes the arabesque to be one's paradigmatic example.

Having cleared up these issues, we may now return to the musicologist's intuition:

[I]n music as in the other arts (verbal, filmic, literary, painterly) aspects of agency are not continuously displayed, nor are aspects of narration. Both are only intermittently operative. Even the most "expressive" music [...] at times simply swirls or dreams or chugs along in its decorative function. But in this it is essentially no different from painting and literature. It may differ from them only in the balance of these functions. (Newcomb 1997, 133; emphasis in original)

In effect, Anthony Newcomb introduces here what we would dub "the Tibby-Helen continuum," that is, the idea that musical ornamentality (sans formalism) and narrativism not only are not mutually exclusive, they are in fact mutually permeable, continuous with each other, and complementary.

The balance of these functions may differ across the musical repertoire, across different styles and performance practices of pure instrumental music, and even across various renditions of a given musical work, invoking a need to take into account the audiences and traditions to which they appeal as well as what Alperson (2008) recently called "the instrumentality of music" - a richly layered understanding of the art of music in terms of culturally and historically situated practices of human beings. Thus, we are inclined to accept Alperson's suggestion that

we may want to think about instrumental music as encompassing a continuum, from music which approaches the limit, on the one hand, of a pure art of decoration, to music which approaches the limit of full-blown imitation on the other. (Alperson 1992, 227)

Kivy (2009, 131-139) raised a couple of general objections to Newcomb's original suggestion to consider such a continuum. To complete our move in this section of our essay, we shall now answer these objections. Kivy's first objection is that the very idea of such a continuum patently begs the question about the narrative content of pure instrumental music: "[U]nless one simply assumes that absolute music has agents and narrative content [...] one cannot argue about the degree to which it has them" (Kivy 2009, 134; emphasis in original). However, if the continuum concerns modes of listening (broadly construed as modes of human engagement with music or musical phenomena), and if we can admit a posteriori that narrative content is possible, as Stephen Davies (2003) suggested, then Kivy (1993b, 23) has already conceded that he "cannot, in a non-question-begging way, rule out 'impure' listening, tout court, as being listening not 'of the work." In other words, Helen is here to stay.

Kivy's second objection derives its logical force from the Sorites paradox, as Kivy moves to establish that the very idea of a continuum in this case is a non sequitur. If the continuum is a matter of how much narrative content it possesses, then, according to Kivy $(2009,134)$, "that is perfectly consistent with its having, as the formalist insists, none at all, just as the bald man possesses zero degree of hair." However, the appeal to the Sorites paradox is actually unwarranted here given the inherent vagueness of the concepts under discussion. These 
concepts are irrevocably derived from ordinary language. This is clearly the case even with regard to the foundational concepts of musical formalism itself. Heinrich Schenker (1954 [1906], 6), for example, construed the very concept of repetition by means of an analogy with the procreative urge of living creatures. In the final analysis, Kivy's second objection is a red herring. Thus we pre-empt Kivy's objections to the Tibby-Helen continuum.

\section{Musical ornamentality as impurely musical make-believe}

We are now set to address the first question we posed in our introduction to this essay - can Walton's theory of make-believe accommodate the Tibby-Helen continuum? - and also to answer it in the affirmative. The kind of musical make-believe that we wish to explore here is impure in two different senses. It is patently impure in the formalist's sense, as Kivy had argued (1990, 42-67). This need not disturb our present discussion. It is also impure in a particularly Waltonian sense, because it impinges on Walton's characterization of music (in Mimesis as Make-Believe and elsewhere) as an art of imaginative introspection. This is where we propose to read Walton's theory against the grain. We believe that Walton's characterization of music can be resisted on independent philosophical as well as musicological grounds, but we shall leave that for another occasion. Our point is that his theory of make-believe nonetheless allows the kind of move that we propose here, and as we shall see, Walton himself actually approached such ideas at one point, although he never developed this any further.

In Mimesis as Make-Believe Walton (274-289) offered an intriguing account of ornamentality in terms of psychologically inhibited games of make-believe. This account has received surprisingly little attention in the literature, and to the best of our knowledge, it has never been applied to music. According to Walton, ornamental works belong to the category of representations that positively discourage participation, especially the psychological participation that would constitute the experience of being caught up in a story. Works are ornamental insofar as they inhibit or interrupt certain imaginings. Such representations deliberately distance the appreciator from the fictional world or even hinder the imagining of what is fictional, effectively undercutting appreciators' roles as reflexive props. In such cases, Walton contends,

our stance is more akin to that of an onlooker than a participant in games of make-believe, although that we "observe" is not someone's actually playing a game but rather the kind of game that might be played. We step back and examine the prop, contemplating the games it might inspire and the role it would have in them. We may marvel at a work's suitability for use in games of certain sorts; we may be fascinated by the combination of fictional truths it generates (this amounts to an interest in the work world); we may admire the artist's skill and ingenuity in devising ways of generating fictional truths; we may delight in the devices by which participation is inhibited. (Walton 1990, 275)

Walton usefully explicated his notion of ornamentality as psychologically inhibited games of make-believe by suggesting that ornamentality consists in fictional worlds in which other fictional worlds are embedded. Embedding a fictional world within another one puts it at a certain emotional "distance" from us. According to Walton (1990, 287), the first-order world, that is, the world of the framing game, "is frequently very sparse, consisting of scarcely more than the work itself together with, by implication, its artist and his creative activity, and inviting minimal participation." Our participation is in this first-order game of make-believe: 
In participating in it we may imagine that there is another game which we could participate in [...] But imagined participation is not actual participation, and imagined participation, let alone imagining merely that there is a game to participate in, does not constitute involvement in a fictional world. We stand apart from the internal fictional world and observe it through its frame. (Walton 1990, 284)

Walton's theoretical structuring of psychologically inhibited games of make-believe as consisting of two game-worlds, one embedded in or framed by another, makes his theory of ornamentality particularly proximate to the Tibby-Helen continuum. The rudiment of a continuum or a sliding scale is already in place. According to Walton, the inhibitions wherein ornamentality subsists are usually partial and the interruptions are temporary, and different ornamental elements may differ in their capacity to inhibit participation. Also, according to Walton $(1990,283)$, ornamental works remain genuine representations: "Their ornamentality merely alters what they are representations of." The two game-worlds may interrupt or interfere with each other, and they generally interpenetrate. In some cases, their juxtaposition might even be the point of the piece. On the whole, Walton maintains that ornamentality coexists with fullfledged mimesis; it is an aesthetic phenomenon which is much more widespread in art and in life than we tend to acknowledge.

We can neatly map the two poles of the Tibby-Helen continuum onto Walton's dual-game formation. Let us be reminded that E. M. Forster's delightful characters, Tibby and Helen, serve here as idealized placeholders for different modes of human engagement with music or musical phenomena. The kind of game in which Tibby, "who is profoundly versed in counterpoint, and holds the full score open on his knee" (Forster 1963 [1910], 31), participates while listening to Beethoven's fifth symphony exemplifies Walton's first-order game-world which includes the work (the symphony) and, by implication, the artists (the composer and the performers) and their creative activities. In the limiting case, the point of Tibby's game may very well be merely to delight in the devices by which participation is inhibited. This may indeed correspond to Kivy's description of the "empty pleasure" of absolute music. But, as Walton pointed out, the point of such games ordinarily extend to appreciating how suitable the work is for use in games of certain sorts and for generating fictional truths as we appreciate the compositional ingenuity and the performing skills in devising ways for generating such fictional truths. So, beyond the limiting case, Tibby's game is all about reaching out to the second-order world, to the embedded game-world, Helen's game, in which it is fictionally true that she see heroes and shipwrecks in the music's flood. The Tibby-Helen continuum stretches perpendicularly from the framing game of make-believe into the game-worlds embedded therein.

It is important to note why Helen's use of Beethoven's symphony is not illicit. She sees heroes and shipwrecks in the music's flood, which means that she has not forgotten about the primary, framing world. She does not mistake the internal, second-order game-world for the primary, framing world, as though it were the world of the work. Helen-type listening does not amount to using the work as a prop in a way in which it is only fictional that it is to be used. ${ }^{7}$ Only in the limiting case would Helen-type listening indeed be listening "not of the work" in this sense. This dialectic of temptation and resistance fleshes out the idea of artistic recalcitrance pertaining to the musical material and its promise of artistic achievement. Certain musical works tend to inhibit more; hence they require some effort to achieve vivid imagining, which might be essential for playing the piece with musical understanding. Other works tend to inhibit less; hence they require some effort to achieve distance, which might be essential for a musically

\footnotetext{
${ }^{7}$ See Walton 1990, 285.
} 
balanced performance.

The very idea of recalcitrance in this context underscores aspects of what Philip Alperson (2008) calls "the instrumentality of music." Alperson argues for a rich ontology of musical instruments which accommodates their understanding as musically, conceptually, and culturally situated; the musical instrument "as an amalgam of material object, the performer's body, and bodily dispositions as habituated by the developments of various musically related skills" (46). Accordingly, Alperson contends,

the performance of musical works is a kind of musical practice in which the object of aesthetic appreciation is legitimately regarded as the work-in-performance. That is, there is a kind of double consciousness of the performance as a performance of the work as a musical entity and of the performer's achievement in performing the work. (Alperson 2008, 47)

We would like to suggest that the artistic recalcitrance afforded by the Tibby-Helen continuum (as seen from the vantage point of Walton's theory of ornamentality) exemplifies precisely this sort of experience of "twofoldness."

One type of example of the artistic challenge involving what we may dub "Helen-to-Tibby recalcitrance" is found whenever we encounter what music critics often call "cerebral" or "analytic" renditions of otherwise highly expressive works, for example Tchaikovsky's "Pathétique" symphony. Familiarity with the tonal idiom, format, and rhetoric of such works may render them significantly more apt to be experienced "from within," in Walton's sense. Yet a musician may wish to do more than offer listeners means of expressing feelings or emotions. A conductor might want us to experience the first movement of the "Pathétique" symphony not just as an expression of conflicting emotions, ours or someone else's (a musical persona, perhaps), but also as an ingenious symphonic structure. He may show ingenious artistic skill precisely in inhibiting or interrupting the listeners' ability to lose themselves in any second-order fictional world beyond their initial appropriation of the musical sounds. He might hold back a little the tempo of the third movement, a defiant march, in order to let the inner voices and overlapping textures shine through. Such a finely balanced performance would unequivocally show an artistic interest in reflexivity, in the means by which participation is promoted and the kinds of participation one might engage in. For the price of lacking a certain kind of passion in Tchaikovsky, one would gain a fuller understanding of how the music works by being geared toward concrete aspects of the actual performance. Walton contends (1990, 288-289) that this is in general one of the great cognitive values of ornamentality.

The converse category of "Tibby-to-Helen recalcitrance" is even more illuminating. In such cases, if the music is to work at all, reflexivity must give way to, and in effect coexist with, vivid imagining. A relatively simple example is the long trill. Among musical embellishments, the long trill has a special function: the prolongation of a long note. Keyboard instruments are not capable of sustaining long notes or modifying their dynamic level once the action of striking the key has been completed. In his definitive treatise on keyboard techniques, Essay on the True Art of Playing Keyboard Instruments (first part published in 1753; second part in 1787), Carl Philipp Emanuel Bach (1949 [1753/1787], 150) argued that the "empty space" may result in a "consequent monotony due to a lack of sonority." If the score calls for a long note in either the upper or the lower voice, then the long trill is commonly regarded (even where it is not actually

\footnotetext{
${ }^{8}$ See Walton 2011.
} 
specified in the score) as a suitable way for the performer to compensate for the acoustic limitations of the instrument so that "the listener will believe that he is hearing only the original note" (Bach 1949 [1753/1787], 150).

This example shows the prevalence and importance of the idea of enhancement for any complete theoretical understanding of musical ornamentality. The idea of enhancement, which was urged upon Kendall Walton by Patrick Maynard (1991; Walton 1991, 416-420), pertains to cases in which an ornament induces imaginings which direct and vivify one's perception of the thing ornamented. In the case of the long trill, the thing ornamented is the "empty space," which the long note prefigures. Thus the imaginings, which the long trill induces, facilitate the listener's grasp of the unfolding of the phrase's structure.

Importantly, the idea of enhancement emphasizes the roles actual things - their physical features as well as their functions - play in make-believe, and other ways in which fiction and reality are intertwined. No less important is the idea that enhancement may coexist with reflexivity. That is, focusing attention on the physical properties of an object apart from their role in generating fictional truths may still vivify imaginings concerning that object. It is noteworthy that Walton $(1991,417)$ has actually acknowledged that "enhancement of the kind Maynard has in mind is especially important in music, in the ornamentation or embellishment or elaboration of melodies or motives. There is much to be done in the way of explaining what the enhancement of an ornamented melody consists in, and what role imaginings have in the process." To the best of our knowledge, Walton never developed this idea, or any of its theoretical implications, in his published writings.

Another important result of Maynard's suggestion is the extension of Walton's notion of ornamentality to include ornamenting or decorating in the transitive sense (the decoration of actual things in our environment). We can comment on this only very briefly here. In such cases, Walton $(1991,417)$ agrees, "one's attention is likely to be drawn to the thing decorated and to the relation of the decoration to it, and this might distract one from full participation in a game with the decorating representation." This extension significantly opens up the discussion of musical ornamentality to accommodate important questions concerning how music meshes with our social reality. For instance, Ernst Gombrich pointed out that music may follow the laws of social decorum in ways analogous to cases of symbolism in visual decoration. Gombrich wrote:

The minuet, the hymn, the pastoral, the aria, are all associated with moods which the composer can accept of modify much as the decorator can treat the music room, the boudoir, or the garden house by accepting or flouting conventions. (Gombrich 1979, 301)

These are aspects of the musical work-in-performance which call for further exploration in the framework of Walton's theory of ornamentality.

The case of the long trill clearly shows that enhancement in music, even in the simplest case, is indispensable, as opposed to the crude example of the sort of automobile decorations that induce us to imagine that a car is fast (color stripes, trim, or simply the styling of the body). In the latter case, if we remove the embellishment, it would be more difficult, yet still quite possible, to imagine that this car is fast. The embellishment is merely "stuck on" what it decorates. In the case of the long trill, if we remove it, then it will be quite impossible to imagine that the long note persists. An aural gap will remain in the middle of the music. The performance will simply fail. 
The indispensability of embellishments in music received an elaborate theoretical defense across the board in C. P. E. Bach's Essay on the True Art of Playing Keyboard Instruments. Bach (1949 [1753/1787], 79) suggested considering the many uses of embellishments for enhancement (in the sense explored here): "They connect and enliven tones and impart stress and accent; they make music pleasing and awaken our close attention. Expression is heightened by them; let a piece be sad, joyful, or otherwise, and they will lend a fitting assistance." He argued that "embellishments provide opportunities for fine performance as well as much of its subject matter. They improve mediocre compositions. Without them the best melody is empty and ineffective, the clearest content clouded" (79). Importantly, there is a natural emphasis in Bach's argument on the idea that the indispensability of embellishments is not merely a matter of the formal properties of the music, but rather enables us to appreciate music as work-inperformance, in Alperson's (2008) sense.

Another, strikingly different example of enhancement is found in Arnold Schoenberg's Piano Piece op. 11, no. 1 (see Fig. 1). One of the most distinct characteristics of common-practice tonality is its ability to convey the sense of directed motion toward a goal. This goal is achieved through a "cadence," a closing formula which contributes to the affirmation of tonality. Schoenberg's "emancipation of the dissonance" in such works as his Piano Piece op. 11, no. 1 yields an abundance of unresolved dissonances, which obscure the tonal center. As Schoenberg $(1975,134)$ himself admitted, when tonality is thus abandoned, "the necessity for fortifying the key may be questioned." Schoenberg argued that in such cases the recalling of tonal centers would not compensate for the absence of directed motion. Yet he also argued that unity and coherence cannot be achieved solely by means of tonality:

[T] here are other laws that music obeys, apart from these [i.e., the laws of sound at the origin of tonality] and the laws that result from the combination of time and sound: namely, those governing the working of our minds. This latter forces us to find a particular kind of layout for those elements that make for cohesion. (Schoenberg 1975, 259)

Figure 1. Arnold Schönberg, 3 Klavierstücke für Klavier, op. 11/1

C Copyright 1995 by Wiener Urtext Edition, Musikverlag Ges.m.b.H. \& Co., K.G., Wien/UT 50195

Schoenberg $(1995,249)$ approached the cadence in its role as "restoration of the state of rest." He maintained that when tonal means are unavailable, this state of rest can be restored by other means of articulation. In op. 11, no. 1, Schoenberg replaced the harmonic cadence by ritardando and langsamer markings that served as means of punctuation so that beginning and ending could be clearly delimited. In effect, the embellishment of tempo carries the musical rhetoric of the piece. The performer must vividly imagine closure for the music to work. Schoenberg's atonal idiom in this piece palpably makes enhancement musically indispensable. If we remove the embellishment of tempo, that is, if we fail to make the gesture in performance, or if we refuse to imagine that this is closure, then the music is bound to fail. We maintain that this sort of enhancement by means of gesture is vital to many other contemporary musical idioms and underlie a mode of listening which is conducive to the appreciation of such music, one which unsympathetic listeners often refuse to engage in.

Another example is needed in order to show a distinguishing case: the advent of "Tibby-to- 
Helen recalcitrance" which does not involve enhancement. Consider Frédéric Chopin's piano etude op. 10, no. 6 (see Fig. 2). This piece calls our immediate attention to its highly chromatic harmony. It displays a four-part polyphonic texture with chromatic sixteenth-note figuration occurring within the inner voices. The intricateness of the polyphonic structure, together with the presence of decorative semi-tonal movement, leads to increased tension among all four layers. This creates a "centrifugal force" which drives the large-scale tonal plan of the piece toward distant tonal relationships. ${ }^{9}$ The extended function of the chromatic figuration ultimately re-defines the performer's considerations. Normally, performing an etude requires special attention to a particular technical challenge. A successful performance of the etude amounts to the attainment of a pre-assigned goal in the performer's learning process. However, in this particular etude, the ornamental figuration is not merely a subtle accompaniment which only requires advanced playing technique; rather, the figuration also significantly intensifies the tonal motion, the continuity, and the overall tension of the piece. Without it, only a bare harmonic skeleton is left, marked by reduced tension and motion. Without it, the ground for remote tonal relationships in the large-scale tonal plan weakens significantly.

Figure 2. Frederic Chopin, 12 Etudes, op. 10/6

C Copyright 1973, 2005 by Wiener Urtext Edition, Musikverlag Ges.m.b.H. \& Co., K. G., Wien/UT 50205

In this piece, the particular artistic challenge for the performer is to move beyond the normal focus in this genre on technique, and hence to reconsider the expressive range of his playing. This artistic challenge pertains to "Tibby-to-Helen recalcitrance" in the sense that expressive playing in this piece presupposes reflexivity: Acute awareness of the broad effect of the chromatic figuration on harmonic motion, tonal tension, and the large-scale tonal plan - the areas which, in the genre of the etude, patently inhibit psychological participation. Such reflexivity determines an expressive form of playing which enables the performer to clearly distinguish the different layers from one another while emphasizing the tense interaction among them as well.

\section{Musical ornamentality and thoughtwriting}

From the vantage point of Walton's theory of onrnamentality as psychologically inhibited games of make-believe, the gist of musical ornamentality is reflexivity. Ornamentality curtails imaginative immersion in a work-world as it deflects the appreciator back to the world of a framing game, which consists of the work itself together with the performer and his creative activity, and by implication also the composer (if he is not also the performer) and his creative activity. We suggested that the reflexivity pertaining to musical ornamentality involves a kind of double consciousness (or twofoldness) of the musical performance as a performance of the work as musical entity and of the performer's achievement in performing the work. We also suggested that deflecting back to the framing world-game - that is, becoming interested in the means by which imaginative participation is promoted and the kinds of participation one might engage in - involves the appreciation of significant connections with our social environment and with our lives. Importantly, such double consciousness pertains not only to the impurely musical make-believe of the performer but also to that of the (non-performing) listener. As Walton suggested long ago (1987, 78), the listener's appreciation involves some sort of

\footnotetext{
${ }^{9}$ See Finlow $(1992,72)$.
} 
empathy with the act of making the sounds. That is, appreciation by performing is primary even when we refer to the experience of a (non-performing) listener.

We can now turn to the second question, which we posed in the introduction to our essay - how may this conception of musical ornamentality intervene in the current formalist-narrativist debate concerning the problem of absolute music? In the previous sections of our essay, we carefully traced and explicated the situation. Paying one last tribute to our loyal literary pathfinders, Tibby and Helen, we can put matters succinctly: Tibby and Helen can be seen as belonging with each other in the sense that Helen's introspectively imaginative game-world is framed (and psychologically inhibited) by Tibby's reflexive yet imaginatively enhancing gameworld; musical ornamentality consists in the mutual, two-way artistic recalcitrance which traverses this dual-world formation. This dynamic theoretical construal of musical ornamentality steers clear of both the Scylla of formalism and the Charybdis of the persona theory.

It is time to place the last piece in our theoretical puzzle. In a recent paper entitled "Thoughtwriting - In Poetry and Music," Walton (2011) advanced a different literary model for understanding musical experience. Walton is now suggesting that music and music-making can frequently be understood in terms of what he dubs "thoughtwriting," that is, as "texts" which are composed "for others to use in expressing their thoughts (feelings, attitudes)" (455). The paradigmatic example for thoughtwriting, Walton argues (468-469), is lyric poetry, which, in contrast to novels, for instance, is especially likely to express thoughts or ideas in a manner that the reader will find particularly apt for his expression. Thus he means to deflect not only the idea of hypothetical narrators and musical personae, whose prevalence and importance in music, he believes, "have been seriously exaggerated" (459) but also reduce the prominence of novels or stories (hence the prominence of the notion of "storytelling") in the explanation of readings (silent ones included) as performances. ${ }^{10}$

"Poetry and music," Walton contends, "are strikingly similar in their propensity to function as thoughtwriting," (473). Thoughtwriting in music requires that we follow along, thinking the music as we listen. "In "performing' music in these ways," he writes, "listeners are likely to be using the sounds (the sound types, anyway, or tokens of the types they hear) to express their own feelings or emotions, or feelings or emotions they try on, ones they experience at least in imagination" (470).

Yet Walton does not offer any conception for a mechanism of appropriation for music. If music is a perceptual art (in contrast to literature [Walton 1990, 334]), then the application of Walton's new literary model to music calls for an elaboration of such a mechanism. The very idea of musical performance as some sort of "text" which is presented for others to use for their own expression requires further explication. We maintain that a suitable conception for a mechanism of appropriation for Walton's new idea of thoughtwriting in music is actually ready at hand in our present suggestion to explain musical ornamentality as psychologically inhibited games of make-believe. In order to clearly distinguish Walton's idea of appropriation in music from cases of mere arousal of thoughts (feelings, attitudes) by means of music, Walton's notion of appropriation in music requires the sort of reflexivity which we expounded in the previous section of this paper. To appropriate musical sound, to be able to utilize it, would necessitate some reflexive know-how. Of course, this seems quite trivial when we think of thoughtwriting in the case of a listener who happens to be also the actual performer of the music.

\footnotetext{
${ }^{10}$ See Kivy 2006.
} 
Our suggestion complements and completes Walton's recent idea of thoughtwriting in music in the following ways. It underscores the full import of music as a performing art by locating the germ of thoughtwriting in the double consciousness of the performance as a performance of the work as a musical entity and of the performer's achievement in performing the work. This significantly expands and enriches the scope of what we may regard as the "text" offered for appropriation in musical performances. The sound offered for appropriation is imbued with understanding of the circumstances of its introduction into the listener's life. That is, the impression the musical sound makes on us is connected with "the whole range of our language games," as Wittgenstein (1980, 51-52) put it. This is particularly true when complex phenomena such as tunes, rhythmic patterns, and musical gestures are presented for possible use by the listener or performer, as the examples from Schoenberg and Chopin in the previous section show. It also accounts for differences in thoughtwriting across different types of music, and across different types of listeners. Ultimately, such a contextually rich conception of thoughtwriting undercuts the force of the standard formalist charge of begging the question about the purported meaning of pure instrumental music.

Finally, our suggestion pulls together Walton's insight in Mimesis as Make-Believe that the psychological distance afforded by ornamentality "makes for less direct but more significant connections with our lives" (288) and his recent idea of experiencing something "from within," of making an expression our own, thinking the music that we hear assertively ourselves. ${ }^{11}$ Conceived in terms of musical ornamentality, as we suggest, the appropriation of musical sound may yield thoughts that connect us to the world in multifarious ways. In contradistinction to formalism and to persona-theory narrativism, the ultimate point of impurely musical makebelieve may be to enable us to appreciate how music meshes with our lives.

\section{References}

Alperson, Philip. "The Arts of Music.” The Journal of Aesthetics and Art Criticism 50.3 (1992): 217-230.

Alperson, Philip. "The Instrumentality of Music." The Journal of Aesthetics and Art Criticism 66.1 (2008): 37-51.

Bach, Carl Philipp Emanuel. Essay on the True Art of Playing Keyboard Instruments. Tr. William J. Mitchell. New York: W. W. Norton, 1949 [1753/1787].

Bell, Clive. Art. New York: Capricorn, 1958 [1914].

Collingwood, Robin George. The Principles of Art. Oxford: Clarendon, 1964 [1938].

Cone, Edward T. The Composer's Voice. Berkeley: University of California Press, 1974.

Davies, Stephen. "Contra the Hypothetical Persona in Music" [1997]. Repr. in Themes in the Philosophy of Music. Oxford: Oxford University Press, 2003. 152-168.

Finlow, Simon. "The Twenty-Seven Etudes and Their Antecedents." The Cambridge Companion to Chopin. Ed. Jim Samson. Cambridge: Cambridge University Press, 1992. 5077.

Forster, E[dward]. M[organ]. Howards End. Harmondsworth: Penguin, 1963 [1910].

Fry, Roger. Vision and Design. London: Chatto \& Windus, 1920.

Gombrich, E[rnst]. H[ans]. The Sense of Order: A Study in the Psychology of Decorative Art. Ithaca, NY: Cornell University Press, 1979.

Hanslick, Eduard. On the Musically Beautiful: A Contribution towards the Revision of the

\footnotetext{
${ }^{11}$ See Walton (2011).
} 
Aesthetics of Music. Tr. Geoffrey Payzant. Indianapolis: Hackett, 1986 [1885].

Hintikka, Jaakko. "The Longest Philosophical Journey: The Quest of Realism as a Common Theme in Bloomsbury." The British Tradition in 20th Century Philosophy. Proceedings of the 17th International Wittgenstein Symposium. Eds. Jaakko Hintikka and Klaus Puhl. Vienna: Hölder-Pichler-Tempsky, 1995. 11-26.

Kant, Immanuel. The Critique of Judgement. Tr. J. C. Meredith. Oxford: Oxford University Press, 1952 [1790].

Kivy, Peter. Music Alone: Philosophical Reflections on the Purely Musical Experience. Ithaca, NY: Cornell University Press, 1990.

Kivy, Peter. The Fine Art of Repetition: Essays in the Philosophy of Music. Cambridge: Cambridge University Press, 1993a.

Kivy, Peter. "Listenings: A Response to Alperson, Davies, and Howard." The Journal of Aesthetic Education 27 (1993b): 22-30.

Kivy, Peter. Introduction to a Philosophy of Music. Oxford: Oxford University Press, 2002.

Kivy, Peter. The Performance of Reading: An Essay in the Philosophy of Literature. Malden, MA: Blackwell, 2006.

Kivy, Peter. Antithetical Arts: On the Ancient Quarrel between Literature and Music. New York: Oxford University Press, 2009.

Kristeller, Paul Oskar. "The Modern System of the Arts" [1951-1952]. Repr. in Renaissance Thought and the Arts: Collected Essays, exp. edition. Princeton, NJ: Princeton University Press, 1990. 163-227.

Levinson, Jerrold. Music, Art, and Metaphysics. Ithaca, NY: Cornell University Press, 1990.

Maynard, Patrick. "Real Imaginings." Philosophy and Phenomenological Research 51.2 (1991): 389-394.

Newcomb, Anthony. "Action and Agency in Mahler's Ninth Symphony, Second Movement." Music and Meaning. Ed. Jenefer Robinson. Ithaca, NY: Cornell University Press, 1997. 131153.

Robinson, Jenefer. Deeper than Reason: Emotion and Its Role in Literature, Music, and Art. Oxford: Oxford University Press, 2005.

Schenker, Heinrich. Harmony. Tr. Elisabeth Mann Borgese. Chicago: University of Chicago Press, 1954 [1906].

Schoenberg, Arnold. Style and Idea. Tr. Leo Black. Ed. Leonard Stein. Berkeley: University of California Press, 1975.

Schoenberg, Arnold. The Musical Idea and the Logic, Technique, and Art of Its Presentation. Ed. and tr. Patricia Carpenter and Severine Neff. New York: Columbia University Press, 1995.

Tormey, Alan. The Concept of Expression: A Study in Philosophical Psychology and Aesthetics. Princeton, NJ: Princeton University Press, 1971.

Walton, Kendall L. "What Is Abstract about the Art of Music?" The Journal of Aesthetics and Art Criticism 46 (1986): 351-364.

Walton, Kendall L. "Style and the Products and Processes of Art." The Concept of Style, rev. edition. Ed. Berel Lang. Ithaca, NY: Cornell University Press, 1987. 72-103.

Walton, Kendall L. "The Presentation and Portrayal of Sound Patterns." Human Agency: Language, Duty and Value. Eds. Jonathan Dancy, Julius Matthew Emil Moravcsik, and Christopher Charles Whiston Taylor. Palo Alto, CA: Stanford University Press, 1988. 237257.

Walton, Kendall L. Mimesis as Make-Believe: On the Foundations of the Representational Arts. Cambridge, MA: Harvard University Press, 1990.

Walton, Kendall L. "Reply to Reviewers." Philosophy and Phenomenological Research 51.2 (1991): 413-431. 
Walton, Kendall L. "Listening with Imagination: Is Music Representational?" The Journal of Aesthetics and Art Criticism 52 (1994): 47-61.

Walton, Kendall L. "Projectivism, Empathy and Musical Tension." Philosophical Topics 26 (1999): 407-440.

Walton, Kendall L. "Thoughtwriting - In Poetry and Music.” New Literary History 42 (2011): 455-476.

Walton, Kendall L. "Two Kinds of Physicality in Electronic and Traditional Music." Bodily Expression in Electronic Music: Perspectives on Reclaiming Performativity. Eds. Deniz Peters, Gerhard Eckel, and Andreas Dorschel. New York: Routledge, 2012. 114-221.

Wittgenstein, Ludwig. Culture and Value. Tr. Peter Winch. Ed. Georg Henrik von Wright. Chicago: University of Chicago Press, 1980.

Wollheim, Richard. Painting as an Art. Princeton, NJ: Princeton University Press, 1987 